\title{
벨기에의 ODA 현황
}

\section{I . 대외원조법 제정 여부}

ㅁ 벨기에는 2003년까지 무상(grants)원조는 외교부 (1999년 대외협력법에 근거)가, 유상(soft loans) 원조는 재무부(1997년 대외재정지원 행정명령국회심의를 거치지 않은 행정 결정)가 별도로 관장 해 오다, 2003년 대외재정지원 행정명령을 개정, 유상원조 업무를 외교부로 이관하고 2004년 예산 부터 유무상 원조를 외교부 예산으로 편입시켰음. - 유무상원조 예산의 통합은 예산상 단일화가 바 람직스럽다는 예산처의 권고를 외교부와 재무 부가 수용함으로써 이루어지게 되었음.

- 유상원조는 상기 1999년 대외협력법에 규정되 어있지 않으며 대외재정지원 조례 외에 근거가 되는 상위 법규는 없음.

\section{II. 대외원조 시행 기관}

ㅁㅇㄱ교부 산하의 벨기에 기술협력청(Belgian Technical Cooperation)에서 유 - 무상 양자 지원 을 전담하며 국제기구 등을 통한 다자적 원조는 외 교부 및 해당 부처에서 담당함.

\section{III. 유상원조와 무상원조의 비율}

ㅁ원조의 대부분은 무상원조 형태이며 유상원조는 극히 일부분임.

-2004년 총액 기준 무상원조 98\%, 유상원조 2\%

\section{IV. 해외긴급재난 발생시 자국민 및 피해국에 대한 지원체제와 관련한 법령 유무}


ㅁ벨기에 자국민에 대한 재난관련 지원은 영사국에 서 담당하며 대외 원조와는 별도 체제로 구성

민급재난 지원은 2 단계로 구성되어 있음.

-1 단계:외교부 별도 예산으로 연간 1 백만 유로를 긴급구호기금으로 마련, 수상실의 주도로 관계 장관회의를 거쳐 1 차 구호품(식품, 의약품, 임시 거주 용구 등) 구입 및 수송(벨기에 Red Cross 가 주관)
-2단계:1996년 대외 긴급구호 및 재건지원 행정 명령에 의해 연간 22 백만 유로의 긴급 구호예산 을 마련해 놓고 있으며 이중 10 백만유로는 $\mathrm{UN}$ CAP (Consolidated Appeal Process)에, 12백 만 유로는 벨기에 $\mathrm{NGO}$ 를 통한 지원에 투입(상 기 1항의 1999 년 대외협력법상의 무상원조와는 별도 체제로 운영)

[자료:주벨기에 대사관] 